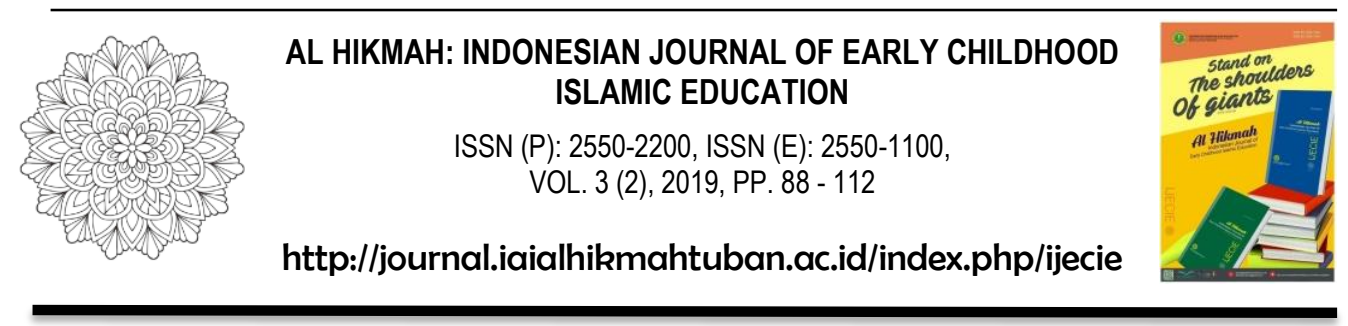

\title{
PEMBELAJARAN KAPILARITAS TERHADAP PERTUMBUHAN TANAMAN UNTUK MELATIH KREATIVITAS ANAK USIA DINI
}

\author{
Adhiesta Kurnia Fikri Rosandi \\ Prodi Pendidikan Islam Anak Usia Dini, STAI Al Hikmah Tuban \\ rosandiadhiesta@gmail.com
}

\begin{abstract}
Abstrak
Penelitian ini bertujuan untuk mendeskripsikan kreativitas anak usia dini melalui pembelajaran kapilaritas terhadap pertumbuhan tanaman pada kelompok B TK PKK Tunas Bangsa, Soko, Tuban. Penelitian ini menggunakan metode penelitian deskriptif kuantitatif dengan jenis penelitian eksperimen. Desain penelitian ini adalah Pre-Experimental Designs menggunakan One-Group Pre-Test-Post-Test Designs. Berdasarkan hasil analisis data penelitian dapat disimpulkan bahwa hasil pretest dan posttest dilakukan uji gain ternormalisasi untuk mengetahui adanya peningkatan kreativitas anak sebelum dan sesudah pembelajaran. Hasilnya, terjadi peningkatan kreativitas anak pada pembelajaran kapilaritas terhadap pertumbuhan tanaman dengan $n$-gain sebesar 0.4 dengan kriteria sedang.

Kata Kunci: Kapilaritas, Pertumbuhan Tanaman, Kreativitas Anak Usia Dini.
\end{abstract}

\begin{abstract}
This research aims to describe the creativity of early childhood through learning capillarity towards plant growth in group B TK PKK Tunas Bangsa, Soko, Tuban. This Research using quantitative descriptive research methods with the type of experimental research. The design of this study is PreExperimental Designs using One-Group Pre-Test-Post-Test Designs. Based on the results of the analysis of the research data it can be concluded that the results of the pretest and posttest are normalized gain tests to determine an increase in children's creativity before and after learning. The result, an increase in children's creativity in capillary learning on plant growth with $n$ gain of 0.4 with moderate criteria.
\end{abstract}

Keywords: Capillarity, plant growth, creativity of early childhood. 


\section{PENDAHULUAN}

Ilmu Pengetahuan Alam telah banyak mengenalkan kita tentang ilmu Alam baik yang ada di bumi maupun di luar angkasa. Bumi tempat kita tinggal dihuni oleh tiga macam makhluk hidup, yaitu Manusia, hewan, dan tumbuhan. Manusia diciptakan oleh Allah SWT sebagai makhluk yang paling istimewa dibandingkan dua makhluk lainnya yaitu mempunyai akal dan pikiran. Anugerah yang luar biasa ini sudah seharusnya untuk selalu disyukuri, maka tak heran manusia mampu meneliti kejadian dan fenomena yang terjadi di Alam. Tumbuhan merupakan satu-satunya makhluk hidup yang dapat hidup mandiri karena tumbuhan disebut sebagai makhluk hidup autotroph yaitu makhluk hidup yang mampu memproduksi makanan sendiri dengan melakukan fotosintesis. Hasil fotosintesis pada tumbuhan adalah berupa oksigen yang dapat dihirup oleh manusia dan hewan, serta energy (ATP) yang digunakan oleh tumbuhan untuk bertahan hidup. Proses yang terjadi pada tumbuhan ini tentunya harus diajarkan pada anak sejak usia dini agar mereka terlatih untuk menyayangi dan menghargai sesama makhluk hidup. Anak-anak harus sadar dari dalam dirinya sendiri bahwa makhluk hidup itu saling membutuhkan dan tidak dapat hidup seorang diri.

Anak usia dini merupakan individu yang unik dimana ia masih dalam tahap awal perkembangan baik itu fisik, motorik, kognitif, sosioemosional, kreativitas, bahasa, dan komunikasi. Mereka akan senang mencoba banyak hal baru dalam hidupnya, oleh karena itu anak usia dini memiliki rasa ingin tahu yang sangat tinggi. Rasa ingin tahu inilah sebagai pondasi awal dalam sebuah pembelajaran karena jika anak sudah memiliki rasa penasaran maka dia akan semangat untuk mencari tahu hal apa yang sebenarnya terjadi. Guru akan bertindak sebagai fasilitator bagi anak untuk menanya, menyelidiki, mengeksplorasi, mengkomunikasikan, hingga menyimpulkan kejadian- 
kejadian di sekitar kita. Anak usia dini harus belajar secara bebas dan tanpa tekanan.

Keselarasan peran guru dan orang tua sangat penting dalam pertumbuhan dan perkembangan anak usia dini untuk membentuk manusia seutuhnya. Manusia yang berkualitas terbentuk dari peran orang-orang disekitarnya dan lingkungan yang berkualitas. Lingkungan juga harus dapat memberikan kesempatan pada anak untuk mengeksplorasi berbagai pengetahuan dan pengalaman dalam berbagai suasana belajar dan membuat anak nyaman, senang, serta penuh makna dalam belajar.

Pendidikan anak usia dini (PAUD) meliputi seluruh upaya dan tindakan yang dilakukan oleh pendidik dan orang tua dalam proses perawatan, pengasuhan, serta pemberian pendidikan pada anak dengan menciptakan aura dan lingkungan dimana anak dapat mengeksplorasi pengalaman yang memberikan kesempatan kepadanya untuk mengetahui dan memahami pengalaman belajar yang diperolehnya dari lingkungan, melalui cara mengamati, meniru, dan bereksperimen yang berlangsung secara berulang-ulang dan melibatkan seluruh potensi kecerdasan anak (Mursid, 2015). Pendidikan untuk anak usia dini telah diatur oleh Negara yang tertuang dalam Peraturan Peraturan Menteri Pendidikan Dan Kebudayaan Republik Indonesia Nomor 146 Tahun 2014 tentang kurikulum 2013 pendidikan anak usia dini yang menyatakan bahwa Pendidikan Anak Usia Dini (PAUD) merupakan suatu upaya pembinaan yang ditujukan kepada anak sejak lahir sampai dengan usia 6 (enam) tahun yang dilakukan melalui pemberian rangsangan pendidikan untuk membantu pertumbuhan dan perkembangan jasmani dan rohani agar anak memiliki kesiapan dalam memasuki pendidikan lebih lanjut. Tujuan untuk mendidik semua anak masih sukar dipahami, namun tujuan tersebut harus tetap diwujudkan. 
Seperti yang dikatakan Sekretaris Menteri Pendidikan Amerika Margaret Spellings (dalam Morrison, 2012) "Tugas seorang guru PAUD adalah memastikan semua anak memiliki pengetahuan dan keterampilan untuk meraih kesuksesan".

Seorang ilmuwan pendidikan Jean Piaget (dalam Morrisson, 2012) mendedikasikan hidupnya untuk melakukan eksperimen mengamati anakanak (termasuk anaknya sendiri). Piaget menyatakan bahwa seorang anak dapat mengembangkan kecerdasan melalui pengalaman/praktik langsung di lingkungan fisik karena pengalaman praktik dapat menjadi dasar bagi kemampuan otak untuk berpikir dan belajar. Anak akan lebih mengingat apa yang diajarkan oleh guru dengan berbagai permainan dan pengalaman yang bermakna karena anak usia 0-6 tahun adalah masa anak-anak senang melakukan permainan yang menarik menurutnya.

Teori perkembangan kognitif piaget membagi tahap perkembangan menjadi beberapa kelompok umur. Salah satunya pada anak usia 2 sampai 7 tahun berada pada tahap praoperasional dengan konsep dasar pemikiran simbolik dimana anak-anak menggunakan simbol seperti kata-kata atau gambaran dalam pikiran untuk menyelesaikan masalah dan memikirkan benda-benda dan orang-orang yang tidak berada bersamanya. Aktivitas dalam bentuk permainan dan praktik memberi kesempatan anak untuk lebih aktif di dalam kelas.

Menurut hasil peringkat Trends in Mathematics and Science Study (TIMSS) yang merupakan sebuah riset internasional untuk mengukur kemampuan anak-anak kelas 4 dan kelas 8 bidang matematika dan IPA, pada tahun 2015 Indonesia menempati peringkat 45 dari 50 negara di bidang matematika, sedangkan di bidang sains Indonesia menempati peringkat 45 dari 48 negara. Tahun 2018, hasil survey Programme for International 
Student Assessment (PISA) yang merupakan pengujian yang diinisiasi oleh Organisation for Economic Cooperation and Development (OECD) untuk mengevaluasi sistem pendidikan di 77 negara yang disurvei, Indonesia menempati peringkat 69 dari 77 negara dibidang sains dengan skor kompetensi sebesar 396 yang masih di bawah rata-rata OECD sebesar 489. Hal ini seakan membuktikan bahwa pembelajaran sains harus diajarkan sejak dini. Menurut Gardner (dalam Mulyasa, 2017) perkembangan otak manusia mengalami lompatan dan berkembang sangat pesat pada usia dini, yakni mencapai $80 \%$. Ketika dilahirkan di dunia, anak telah mencapai perkembangan otak $25 \%$ sampai usia 4 tahun perkembangannya mencapai $50 \%$, dan sampai usia 8 tahun mencapai $80 \%$; selebihnya berkembang sampai usia 18 tahun. Hasil riset ini menyatakan bahwa perkembangan anak yang signifikan terjadi pada kurun waktu 4 tahun hingga 18 tahun. Setelah itu, perkembangan otak anak akan mengalami stagnasi, oleh karena itu mulai usia 4 tahun anak-anak harus dieksplorasi kemampuannya secara maksimal.

Sains berasal dari kata science yang berarti pengetahuan. Ibrahim (2010) mendefinisikan sains adalah studi sistematika tentang alam dan bagaimana alam itu mempengaruhi kehidupan di lingkungan kita. Carin \& Sund (1989) menyatakan bahwa sains memiliki tiga elemen yaitu sikap, proses, produk. Sikap merupakan perilaku seseorang dalam mengembangkan rasa ingin tahu, bekerjasama dengan teman, toleran, tekun, dan masih banyak yang lain. Proses adalah langkah-langkah dalam proses penyelidikan dan menyelesaikan masalah, seperti: merumuskan hipotesis, melakukan percobaan, mengumpulkan data, menganalisis data, serta menyimpulkan hasil penyelidikan. Produk adalah hasil, fakta, teori, prinsip, hukum tentang sains dari proses metode ilmiah. 
Ilmu tentang sains sangat erat hubungannya dengan kehidupan sehari-hari yang dilakukan oleh komponen biotik maupun abiotik. Keduanya akan selalu berkesinambungan menimbulkan hukum sebab akibat. Namun, diantara ketiga makhluk hidup yaitu manusia, hewan dan tumbuhan. Makhluk hidup yang mampu membuat makanan sendiri adalah tumbuhan dengan proses fotosintesis yang akan menghasilkan oksigen dan karbohidrat. Oksigen yang dihasilkan oleh tumbuhan sangat dibutuhkan oleh hewan dan manusia untuk bernafas, maka dari itu tanaman hijau sangat penting bagi kehidupan kita. Hal ini tentu penting untuk ditanamkan pada anak usia dini agar selalu merawat dan menyayangi tumbuhan karena dapat menghasilkan oksigen yang kita hirup sehari-hari.

Proses pertumbuhan pada tanaman melibatkan beberapa organ yaitu akar, batang, dan daun. Akar bertugas untuk menyerap air dan garam mineral yang akan digunakan untuk fotosintesis. Batang berfungsi sebagai jalur pengangkutan air dan mineral penting yang akan disalurkan ke daun untuk proses fotosintesis. Penyerapan air pada akar melalui celah-celah kecil sehingga air bisa masuk ke dalam akar hingga ke daun. Proses penyerapan air melalui celah kecil tersebut dalam ilmu fisika disebut sebagai hukum kapilaritas.

Pengangkutan air dari akar menuju ke daun melalui pembuluh kayu (xylem) yang digunakan untuk proses fotosintesis, sedangkan hasil fotosintesis diangkut dari daun ke seluruh tubuh tumbuhan melalui pembuluh kulit (floem). Ada 2 Faktor yang mempengaruhi naiknya air atau larutan ke dalam pembuluh kayu (xylem) di akar . Kedua faktor tersebut adalah faktor internal dan faktor eksternal. Faktor internal meliputi tekanan akar, daya kapilaritas, dan daya hisap akar. Xylem mempunyai diameter buluh yang kecil sehingga menghasilkan daya kapilaritas. 
Buluh yang terdapat pada xylem berfungsi sebagai pipa kapiler atau celah kecil sebagai perantara naiknya air ke akar. Peristiwa naiknya air ke akar disertai dengan adanya gaya adhesi antara molekul air dan dinding pembuluh kayu pada akar. Peristiwa ini dinamakan dengan kapilaritas. Tanaman merupakan makhluk hidup yang dapat membuat makanan sendiri (autotroph), tetapi tanaman juga selalu membutuhkan air selama proses pertumbuhan untuk bertahan hidup. Oleh karena itu, peristiwa kapilaritas sangat berpengaruh pada proses pertumbuhan. Tanpa adanya daya kapilaritas yang dimiliki oleh pembuluh xylem, maka tanaman juga akan kesulitan dalam proses mendapatkan air. Hubungan inilah yang akan dibahas pada artikel ini yaitu pengaruh kapilaritas pada pertumbuhan tanaman untuk diterapkan pada anak usia dini. Pengaruh hukum kapilaritas terhadap pertumbuhan tanaman diharapkan dapat untuk melatih kemampuan berpikir kreatif anak usia dini.

Pemikir kreatif adalah pembelajar aktif yang dapat menemukan dan memecahkan masalah, mengenali pola, menggabungkan informasi dengan cara baru, menantang asumsi, membuat keputusan, dan mencari ide-ide baru (Healy, 2004). Bahkan menurut Moran (dalam Wojciehowski \& Ernst, 2018) seseorang yang kreatif memainkan peran kunci dalam kepintaran sehari-hari, kemajuan seni dan sains, bisnis inovasi, interaksi sosial, dan kebijakan publik.

Keterampilan berpikir kreatif adalah dasar sains, yang sangat penting bagi siswa (Jodion Siburian, Aloysius Duran Corebima, Ibrohim, Murni Saptasari, 2019). Optimalisasi keterampilan berpikir sangat penting, karena itu adalah keterampilan hidup yang perlu dikembangkan (Zubaidah, 2010), mengatasi masalah kompleks seiring dengan perkembangan biologis. 
Kreativitas dapat dilatih melalui pengalaman dan proses kehidupan yang kita lalui. Produk kreatif akan muncul bila ada motivasi baik motivasi intrinsik maupun ekstrinsik disertai komitmen yang tinggi untuk mencapai prestasi serta adanya wahana yang memungkinkan munculnya kreativitas (Dwirahmah, 2013). Semakin banyaknya wahana, media, maupun alat peraga yang disediakan untuk mengasah kreativitas, maka semakin tinggi pula potensi kreativitas yang dapat diraih. Penerapan kreativitas dalam program pendidikan untuk meningkatkan kreativitas anak-anak prasekolah, itu dapat dilakukan melalui beberapa kegiatan seperti kegiatan bermain, kegiatan drama, kegiatan literasi awal juga meningkatkan kreativitas. Selain itu, bisa dilakukan dengan membuat kegiatan yang berkaitan dengan lingkungan yang dibuat di kelas dan mendukung kreativitas memengaruhi kreativitas anak-anak secara positif (Dere, 2019).

Guru PAUD sudah seharusnya mampu memberikan kesempatan pada anak-anak untuk mengekspresikan ide-ide mereka, menghargai pemikiran tiap individu, dan mendorong anak-anak untuk berfikir kreatif. Mereka dapat mendorong anak-anak untuk berpartisipasi aktif dalam permainan kreatif. Berdasarkan hasil penelitian (Faizi, Azari, dan Maleki, 2012) stimulasi dengan lingkungan yang diberikan pada anak-anak dan partisipasi aktif dalam kegiatan bersama dengan bahan-bahan alami secara positif dapat meningkatkan kreativitas anak-anak. Oleh karena itu, anak usia dini harus dibiasakan untuk menggunakan bahan-bahan alami yang dapat diperoleh dari lingkungan sekitar. Pembelajaran untuk meningkatkan kreativitas anak dapat diterapkan melalui materi hukum kapilaritas yang berpengaruh pada pertumbuhan tanaman. Peristiwa ini dapat diteliti secara ilmiah melalui eksperimen sederhana yang dapat dilakukan oleh anak usia dini. 
Pembelajaran tentang kapilaritas pada pertumbuhan tanaman ini dapat diterapkan menggunakan strategi pembelajaran Discovery Learning. Penerapan strategi Discovery Learning dapat memberikan kesempatan peserta didik untuk belajar secra aktif, sedangkan guru hanya sebagai fasilitator. Penggunaan discovery learning ditujukan untuk mengubah kondisi belajar yang pasif menjadi aktif dan kreatif, serta mengubah pembelajaran yang teacher oriented ke student oriented (Mulyasa, 2017).

Pembelajaran discovery learning memerlukan lingkungan yang kondusif dan dapat memfasilitasi rasa ingin tahu peserta didik. Penerapan strategi pembelajaran ini dapat dilakukan dengan eksplorasi, eksperimen, serta penemuan-penemuan baru yang belum diketahui oleh peserta didik. Menurut Bruner dalam Muyasa (2017) discovery learning dilakukan melalui observasi, klasifikasi, pengukuran, prediksi, dan penentuan. Sedangkan menurut Robert B. Sund dalam Mulyasa (2017) bahwa discovery merupakan proses kognitif yang disebut dengan the mental process of assimilating concepts and principles in the mind.

Penerapan strategi pembelajaran discovery learning pada anak usia dini, peserta didik dituntut melakukan berbagai kegiatan menghimpun informasi, membandingkan, mengategorikan, menganalisis, mengintegrasikan, mereorganisasi bahan serta membuat kesimpulan dan generalisasi. Bruner mengatakan bahwa pembelajaran dapat berjalan baik dan kreatif ketika guru memberikan kesempatan kepada peserta didik untuk menemukan suatu konsep, teori, aturan, atau pemahaman melalui contohcontoh yang ditemui dalam kehidupannya.

Penerapan strategi pembelajaran discovery learning tentang daya kapilaritas terhadap pertumbuhan tanaman dapat dilakukan selama empat kali pertemuan dengan prosedur operasional sebagai berikut. 


\section{Langkah Persiapan}

a. Menentukan tujuan pembelajaran

b. Melakukan identifikasi karakteristik peserta didik, antara lain kemampuan awal, minat, dan gaya belajar.

c. Menentukan materi pelajaran yaitu tentang daya kapilaritas terhadap pertumbuhan tanaman

d. Menyiapkan instrument penilaian proses dan hasil belajar siswa/peserta didik.

\section{Langkah Implementasi}

\section{Fase 1: Pemberian Rangsangan (Stimulation)}

e. Guru memberikan motivasi awal pada siswa yaitu dengan menyediakan gelas yang telah diisi air kemudian memasukkan ujung tisu ke dalam gelas kemudian mengamati apa yang terjadi pada tisu tersebut.

f. Guru memotivasi siswa untuk bertanya tentang peristiwa yang terjadi pada tisu

\section{Fase 2: Identifikasi Masalah (problem identification)}

g. Guru membantu peserta didik untuk mengidentifikasi masalah untuk merumuskan hipotesis (dugaan sementara)

h. Guru membimbing peserta didik untuk membuat rumusan masalah dalam bentuk pertanyaan atas jawaban sementara yang diajukan.

\section{Fase 3: Pengumpulan Data (Data Collection)}

i. Guru membentuk kelompok beranggotakan 5-6 siswa secara heterogen

j. Guru menyiapkan alat dan bahan untuk eksperimen, yaitu air, gelas plastik, pewarna makanan, dan sawi putih.

Fase 4: Pemrosesan Data (Data Processing) 
k. Guru memberikan tugas pada siswa untuk mengamati hal apa yang terjadi pada sawi putih setelah dicelupkan ke dalam air.

1. Guru membantu siswa untuk mengidentifikasi perubahan warna pada sawi putih.

\section{Fase 5: Pembuktian (Verification)}

m. Siswa melakukan pemeriksaan secara cermat kebenaran dari hipotesis bahwa sawi putih dapat menyerap air karena terjadi perubahan warna pada sawi putih

n. Hasil percobaan tersebut membuktikan bahwa akar, batang, dan daun tanaman dapat menyerap air sehingga akan berpengaruh pada proses pertumbuhan tanaman

o. Untuk membuktikan hal tersebut, guru meminta siswa untuk menanam kedelai pada kapas yang telah diberi air dan diamati pertumbuhannya selama beberapa hari.

\section{Fase 6: Menarik Kesimpulan (Generalization)}

p. Guru bersama siswa membuat kesimpulan tentang kegiatan yang telah dilakukan.

q. Guru meminta siswa untuk mengamati pertumbuhan kecambah dari hari ke hari

r. Guru memberikan reward pada kelompok yang dapat menyelesaikan tugasnya dengan baik

s. Guru mengevaluasi kegiatan yang telah dilakukan bersama.

Pembelajaran hukum kapilaritas terhadap pertumbuhan tanaman ini diharapkan mampu meningkatkan kreativitas anak usia dini karena menggunakan bahan-bahan alami yang terdapat di lingkungan sekitar.

Berdasarkan pengamatan di TK PKK Tunas Bangsa, Soko, Tuban, siswa masih belum terbiasa untuk diajak melakukan pembelajaran menggunakan 
bahan alam, sehingga kemampuan siswa kurang berkembang terutama kemampuan berpikir kreatif. Oleh karena itu, pembelajaran kapilaritas terhadap pertumbuhan tanaman ini diharapkan bisa untuk melatih kreativitas siswa.

\section{METODE}

Penelitian ini menggunakan metode penelitian deskriptif kuantitatif dengan jenis penelitian eksperimen. Desain penelitian ini adalah PreExperimental Designs menggunakan One-Group Pre-Test-Post-Test Designs, karena dalam penelitian ini penulis tidak menggunakan kelompok pembanding.

Hal ini dikarenakan uji coba hanya dilakukan pada satu kelompok saja tanpa adanya kelompok pembanding. Rancangan penelitian ini digunakan untuk memperoleh catatan berupa peningkatan skor berpikir kreatif siswa. Rancangan penelitian dapat digambarkan sebagai berikut:

$$
\begin{array}{lll}
\mathrm{O}_{1} & \mathrm{x} & \mathrm{O}_{2}
\end{array}
$$

Keterangan:

$\mathrm{O}_{1}$ : pretest, bertujuan mengetahui tingkat kemampuan kreatif anak terhadap materi pembelajaran sebelum diberikan perlakuan.

$\mathrm{O}_{2} \quad$ : posttest, bertujuan mengetahui tingkat kemampuan kreatif anak terhadap materi pembelajaran sesudah diberikan perlakuan.

$\mathrm{X}$ : tindakan KBM dengan menggunakan percobaan kapilaritas terhadap pertumbuhan tanaman

(Sugiyono, 2010)

Populasi penelitian ini adalah anak kelompok B di TK PKK Tunas Bangsa, Soko, Tuban tahun pelajaran 2018/2019 dengan jumlah anak sebanyak 25 anak. 
1. Variabel Penelitian

Penelitian ini mempunyai dua variabel yaitu:

a. Variabel Bebas yaitu variabel yang mempengaruhi variable terikat. Dalam penelitian ini variable bebas adalah materi pembelajaran hokum kapilaritas terhadap pertumbuhan tanaman.

b. Variabel Terikat yaitu variabel yang dipengaruhi oleh variabel bebas. Dalam penelitian ini adalah berpikir kreatif anak.

2. Prosedur Penelitian

Prosedur penelitian ini melalui tahap perencanaan, pelaksanaan, observasi, dan refleksi.

a. Perencanaan meliputi perancangan perangkat pembelajaran yang akan digunakan. Dalam hal ini strategi pembelajaran yang digunakan adalah discovery learning dengan materi daya kapilaritas terhadap pertumbuhan tanaman. Pembelajaran dilaksanakan selama 4 kali pertemuan dengan menggunakan media bahan-bahan alam, seperti: sawi putih, pewarna makanan, air, kacang kedelai, kapas, serta gelas air mineral.

b. Pelaksanaan: alokasi waktu pelaksanaan pembelajaran adalah selama empat kali pertemuan. Dimana pada minggu pertama anak diminta untuk mengamati proses kapilaritas yang terjadi pada sawi putih dan menanam kedelai dengan media kapas kemudian mengamati pertumbuhan yang terjadi pada kedelai. Pada pertemuan kedua, ketiga, dan keempat anak diminta untuk membuktikan bahwa ada daya kapilaritas mempengaruhi pertumbuhan tanaman.

c. Observasi: meliputi pengamatan sikap anak selama pembelajaran berlangsung seperti kerjasama, bertanya, melakukan percobaan, keaktifan siswa, kreativitas anak. 
3. Instrumen Penelitian

Instrumen penelitian yang digunakan penelitian ini merupakan instrumen penelitian yang digunakan untuk mengukur kemampuan berpikir kreatif siswa. Adapun indikator yang dinilai melalui instrumen ini adalah sebagai berikut:

Tabel 1. Instrumen Penilaian kemampuan berpikir kreatif

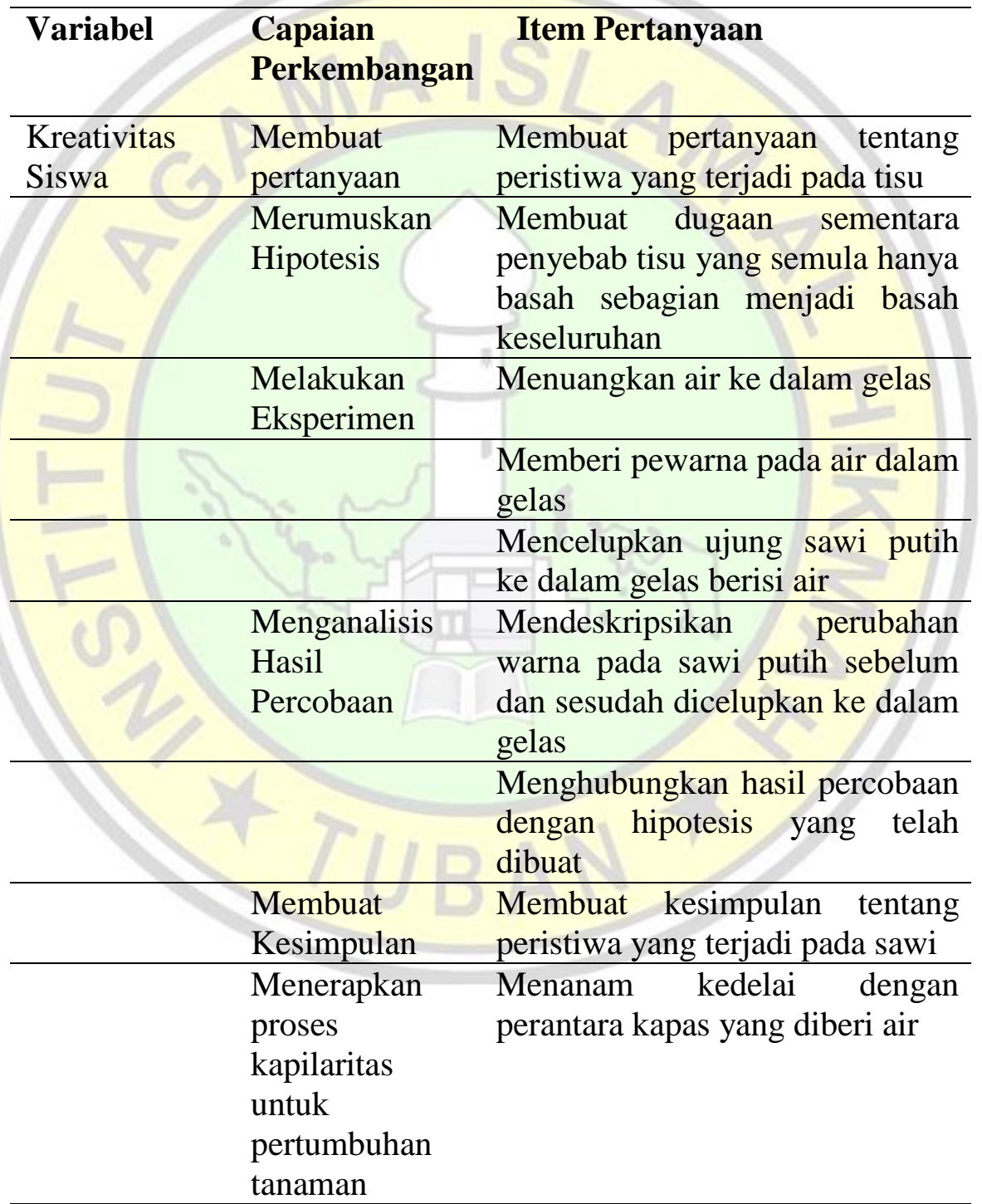

Mengamati pertumbuhan kedelai dari hari ke hari 
Adhiesta Kurnia F.R. (Pembelajaran Kapilaritas Terhadap Pertumbuhan)

\begin{tabular}{|c|c|c|}
\hline Variabel & $\begin{array}{l}\text { Capaian } \\
\text { Perkembangan }\end{array}$ & Item Pertanyaan \\
\hline & $\begin{array}{l}\text { Mengamati } \\
\text { percobaan } \\
\text { menanam } \\
\text { kedelai }\end{array}$ & $\begin{array}{l}\text { Mengukur pertumbuhan tanaman } \\
\text { dari hari ke hari }\end{array}$ \\
\hline & +2 & $\begin{array}{l}\text { Mengamati ada tidaknya air dari } \\
\text { hari ke hari }\end{array}$ \\
\hline & $\begin{array}{l}\text { Mengkomunika } \\
\text { sikan hubungan } \\
\text { pertumbuhan } \\
\text { dengan } \\
\text { kapilaritas }\end{array}$ & $\begin{array}{l}\text { Menganalisis pengaruh air } \\
\text { terhadap pertumbuhan tanaman }\end{array}$ \\
\hline & & $\begin{array}{l}\text { Menganalisis } \\
\text { pertumbuhan tanaman dengan } \\
\text { kapilaritas }\end{array}$ \\
\hline 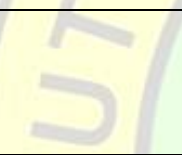 & $\begin{array}{l}\text { Membuat } \\
\text { kesimpulan }\end{array}$ & $\begin{array}{l}\text { Membuat kesimpulan tentang } \\
\text { kapilaritas pada pertumbuhan } \\
\text { tanaman }\end{array}$ \\
\hline & & \\
\hline
\end{tabular}

Tabel 2. Rubrik Penilaian Observasi

\begin{tabular}{|c|c|c|c|}
\hline No & Aspek yang dinilai & Rubrik & Skor \\
\hline 1 & $\begin{array}{l}\text { Membuat } \\
\text { pertanyaan tentang } \\
\text { peristiwa yang } \\
\text { terjadi pada tisu }\end{array}$ & $\begin{array}{l}\text { 1. Anak mampu bertanya } \\
\text { tentang peristiwa yang terjadi } \\
\text { pada tisu dengan tepat dan } \\
\text { mandiri } \\
\text { 2. Anak mampu bertanya } \\
\text { tentang peristiwa yang terjadi } \\
\text { pada tisu dengan tepat tapi } \\
\text { masih dibantu } \\
\text { 3. Anak bertanya tentang } \\
\text { peristiwa yang terjadi pada } \\
\text { tisu tapi kurang tepat } \\
\text { 4. Anak belum mampu bertanya } \\
\text { tentang peristiwa yang terjadi } \\
\text { pada tisu dengan tepat }\end{array}$ & 2 \\
\hline 2 & $\begin{array}{l}\text { Membuat dugaan } \\
\text { sementara penyebab }\end{array}$ & $\begin{array}{l}\text { 1. Anak mampu membuat } \\
\text { dugaan sementara penyebab }\end{array}$ & 4 \\
\hline
\end{tabular}




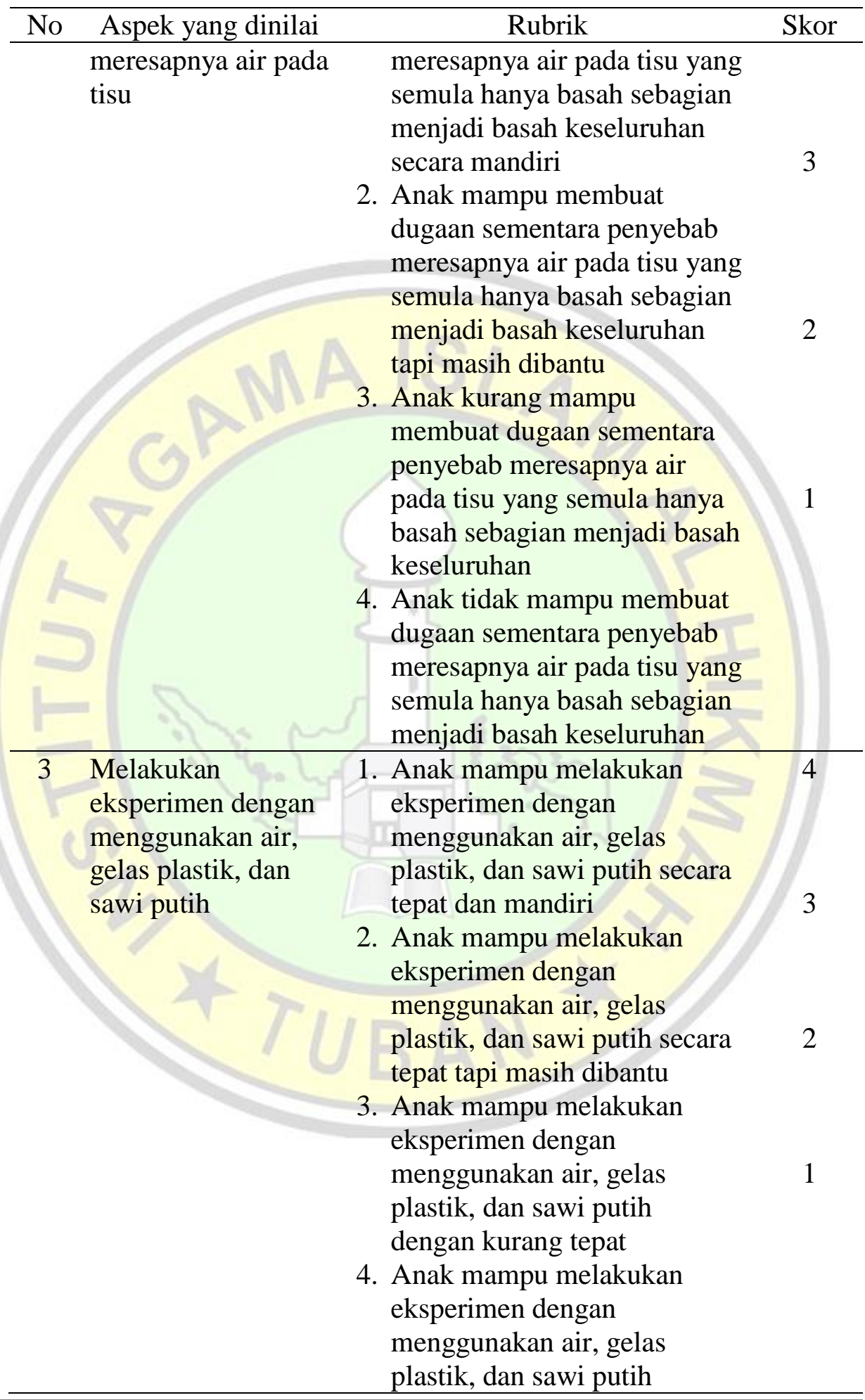




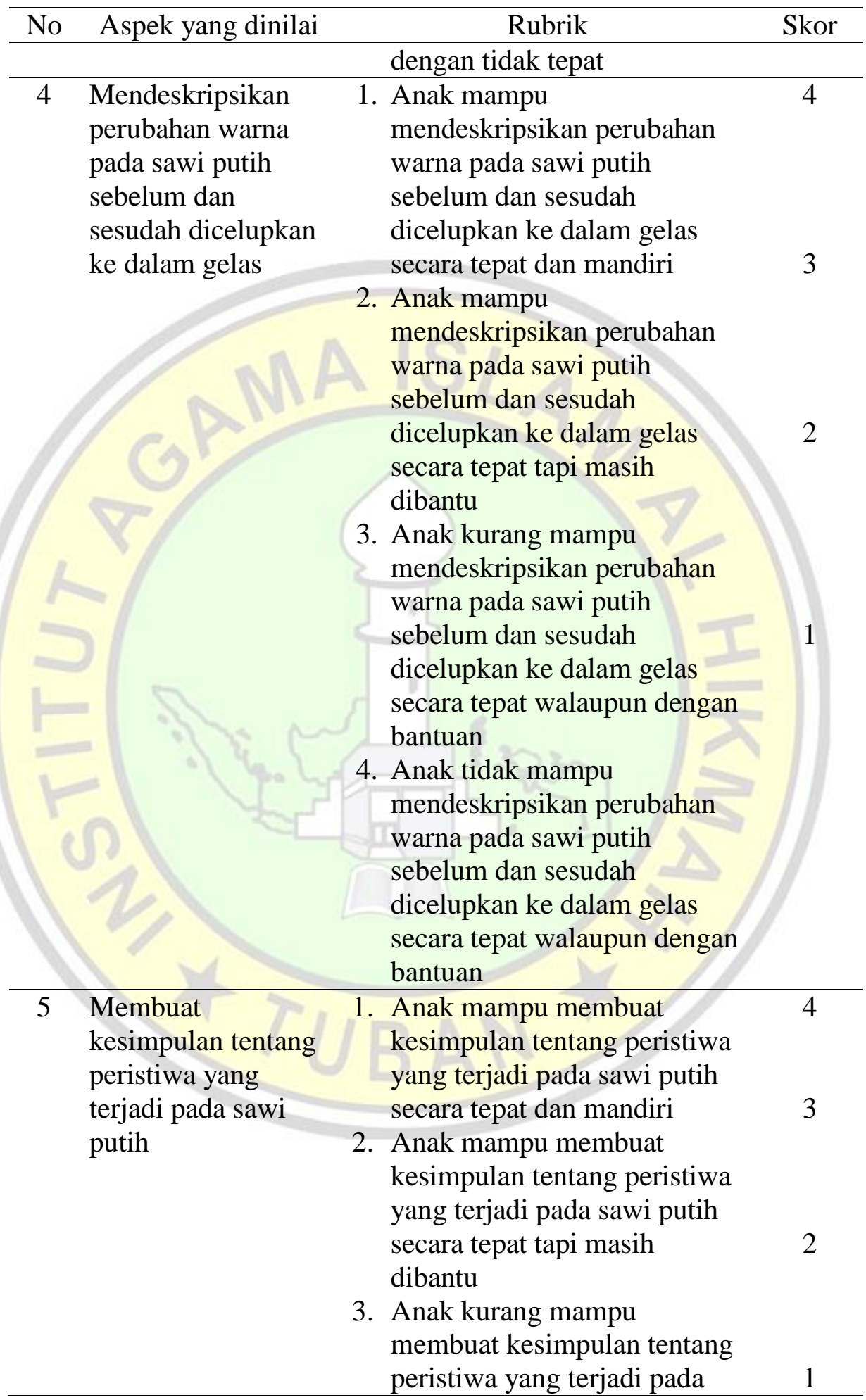




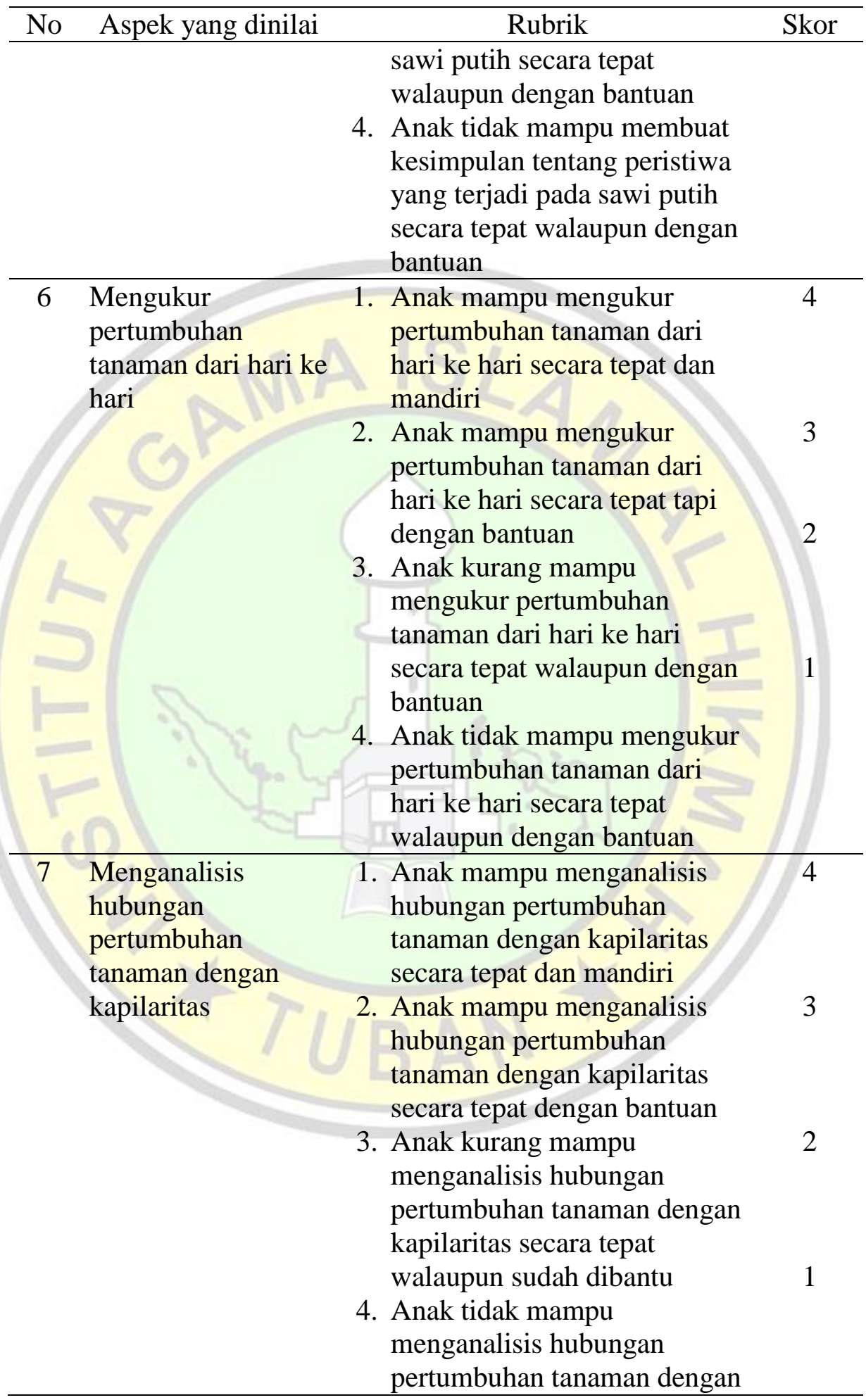


Adhiesta Kurnia F.R. (Pembelajaran Kapilaritas Terhadap Pertumbuhan)

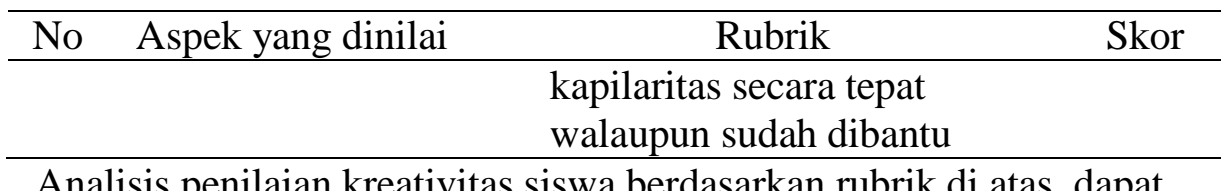
dihitung dengan menggunakan kriteria skor sebagai berikut.

Tabel 3. Skala Likert

\begin{tabular}{cc}
\hline Kriteria & Skor \\
\hline Sangat Setuju (SS) & 4 \\
\hline Setuju (S) & 3 \\
\hline Kurang Setuju (KS) & 2 \\
\hline Tidak Setuju (TS) & 1 \\
\hline
\end{tabular}

(Sumber: Riduwan dalam Adhiesta 2014:51)

Untuk mengetahui skor kemampuan kreativitas anak yang diperoleh, maka digunakan rumus:

$$
\text { Skor kreativitas }(\%)=\frac{\sum \text { Skor yang diperoleh }}{\sum \text { skor maksimal }} \times 100 \%
$$

Persentase yang diperoleh diintepretasikan ke dalam kriteria pada tabel berikut.

Tabel 4. Kriteria Intepretasi Skor

\begin{tabular}{cc}
\hline Kriteria & Penafsiran \\
\hline $1 \%-20 \%$ & Sangat Kurang \\
\hline $21 \%-40 \%$ & Kurang \\
\hline $41 \%-60 \%$ & Cukup \\
\hline $61 \%-80 \%$ & Baik \\
\hline $81 \%-100 \%$ & Sangat Baik \\
\hline
\end{tabular}

(Sumber: Riduwan dalam Adhiesta 2014:52)

Data hasil pretest dan posttest yang diperoleh siswa dapat dianalisis peningkatannya menggunakan analisis $n$-gain (ternormalisasi). Menurut Hake dalam Adhiesta (2016:86) skor peningkatan dapat diperoleh dengan rumus. 


$$
\mathrm{g}=\frac{\left(S_{\text {post }}\right)-\left(S_{\text {pre }}\right)}{\text { skor max }-\left(S_{\text {pre }}\right)}
$$

Keterangan:

g (gain) : peningkatan level penguasaan konsep

$S_{\text {pre }} \quad$ : skor pretes (kreativitas awal pada anak)

$S_{\text {post }} \quad$ : skor posttest (kreativitas akhir pada anak)

Rumus di atas dapat diklasifikasikan kriteria gain sebagai berikut:

g-tinggi $:(\mathrm{g})>0,7$

g-sedang $:(\mathrm{g}) \geq(\mathrm{g}) \geq 0,3$

g-rendah $:(\mathrm{g})<0,3$

\section{HASIL DAN PEMBAHASAN}

Hasil penelitian ini akan diuraikan berdasarkan tujuan penelitian yaitu mendeskripsikan keterlaksanaan pembelajaran kapilaritas terhadap pertumbuhan tanaman di TK PKK Tunas Bangsa, Soko Tuban, mendeskripsikan kemampuan kreativitas siswa saat pembelajaran kapilaritas terhadap pertumbuhan tanaman dilaksanakan.

Pelaksanaan pembelajaran kapilaritas terhadap pertumbuhan tanaman di TK PKK Tunas Bangsa, Soko, Tuban dilaksanakan selama empat kali pertemuan. Metode pembelajaran yang digunakan adalah Discovery learning dimana anak didorong untuk menemukan sendiri pengetahuan yang dipelajari. Keterlaksanaan pembelajaran ini diukur melalui instrument keterlaksanaan pembelajaran yang diamati oleh seorang pengamat.

Tabel 5. Keterlaksanaan Pembelajaran

\begin{tabular}{clcc}
\hline No & Aspek yang diamati & Presentase & Kriteria \\
\hline 1 & Persiapan & $100 \%$ & Sangat Baik \\
\hline 2 & Pelaksanaan & & \\
\hline & a. Pendahuluan & $87 \%$ & Sangat Baik \\
\hline
\end{tabular}


Adhiesta Kurnia F.R. (Pembelajaran Kapilaritas Terhadap Pertumbuhan)

\begin{tabular}{clcc}
\hline & b. Kegiatan Inti & $83 \%$ & Sangat Baik \\
\hline & c. Penutup & $87 \%$ & Sangat Baik \\
\hline 3 & Pengelolaan Kelas & $83 \%$ & Sangat Baik \\
\hline 4 & Suasana Kelas & $87 \%$ & Sangat Baik \\
\hline Rata-rata & $87 \%$ & Sangat Baik \\
\hline
\end{tabular}

Berdasarkan Tabel 5 tersebut terlihat bahwa keterlaksanaan pembelajaran telah dilakukan dengan sangat baik yaitu memperoleh rata-rata 87\%. Hal ini membuktikan bahwa guru telah melaksanakan proses pembelajaran dengan sangat baik. Pembelajaran ini dilaksanakan melalui 4 aspek yang diamati yaitu persiapan, pelaksanan, pengelolaan kelas, dan suasana kelas.Pada tahap persiapan, guru menyiapkan semua kebutuhan yang digunakan saat pembelajaran mulai dari perangkat pembelajaran hingga media dan alat pembelajaran yang digunakan. Persiapan guru memperoleh persentase $100 \%$ karena semuanya sudah disiapkan dengan matang. Kemudian pada saat pelaksanaan pembelajaran kegiatan pertama yang dilakukan adalah pendahuluan yaitu dengan memberikan motivasi pada anakanak mendapat persentase $87 \%$ dengan kategori sangat baik, hal ini dikarenakan anak-anak begitu antusias dengan motivasi yang diberikan oleh guru. Sedangkan pada kegiatan inti mendapat persentase sebesar $83 \%$ dengan kategori sangat baik. Anak-anak dikelompokkan dalam 5 kelompok yang masing-masing kelompok beranggotakan 5 anak. Kemudian masing-masing kelompok akan melakukan eksperimen tentang kapilaritas dan pertumbuhan tanaman kedelai. Anak-anak begitu antusias dengan eksperimen ini sehingga suasana kelas aktif dan interaktif dimana suasana kelas memperoleh persentase $87 \%$ dengan kriteria sangat baik. Sedangkan pengelolaan kelas memperoleh persentase $83 \%$ dengan kriteria sangat baik. Pada aspek penutup 
guru bersama anak untuk membuat kesimpulan dari kegiatan yang telah dilakukan. Hal ini menunjukkan pembelajaran kapilaritas terhadap pertumbuhan tanaman untuk melatih kreativitas anak telah terlaksana dengan sangat baik.

Tujuan selanjutnya pada penelitian ini adalah melatih kreativitas anak melalui eksperimen dengan benda-benda alam yang ada disekitar mereka. Kemampuan kreativitas siswa diukur melalui instrumen pengamatan yang diamati oleh guru pada saat siswa melakukan kegiatan belajar mengajar. Adapun hasil observasi ini telah dilakukan sebelum pembelajaran dilakukan (pretest) dan saat pembelajaran dengan materi kapilaritas ini diterapkan oleh guru (posttest). Observasi dilakukan melalui 7 aspek yang telah dijabarkan pada metode penelitian artikel ini. Hasil ini dihitung menggunakan sistem skor tiap aspek yang diamati. Kemudian dari skor yang diperoleh akan dihitung peningkatan pretest dan posttest dengan N-gain skor. Adapun hasil pengamatan kreativitas anak adalah sebagai berikut:

\section{Tabel 6. Hasil Observasi Kreativitas Anak}

\begin{tabular}{ccccc}
\hline No & Pretest & Posttest & N-Gain & Kriteria \\
\hline 1 & 2.1 & 3.4 & 0.7 & Sedang \\
\hline 2 & 1.9 & 3.1 & 0.6 & Sedang \\
\hline 3 & 1.9 & 2.9 & 0.5 & Sedang \\
\hline 4 & 2.3 & 3 & 0.4 & Sedang \\
\hline 5 & 2.7 & 3.1 & 0.3 & Sedang \\
\hline 6 & 2.4 & 3 & 0.4 & Sedang \\
\hline 7 & 2.6 & 3 & 0.3 & Sedang \\
\hline 8 & 2.4 & 2.9 & 0.3 & Sedang \\
\hline 9 & 2.4 & 3.1 & 0.4 & Sedang \\
\hline 10 & 2.6 & 3.1 & 0.4 & Sedang \\
\hline 11 & 2.3 & 2.9 & 0.4 & Sedang \\
\hline 12 & 2.3 & 2.9 & 0.4 & Sedang \\
\hline 13 & 2.4 & 3.1 & 0.4 & Sedang \\
\hline 14 & 2.1 & 3 & 0.5 & Sedang \\
\hline
\end{tabular}


Adhiesta Kurnia F.R. (Pembelajaran Kapilaritas Terhadap Pertumbuhan)

\begin{tabular}{ccccc}
\hline No & Pretest & Posttest & N-Gain & Kriteria \\
\hline 15 & 2.3 & 3 & 0.4 & Sedang \\
\hline 16 & 2.4 & 2.6 & 0.1 & rendah \\
\hline 17 & 2.3 & 3 & 0.4 & Sedang \\
\hline 18 & 2.4 & 3 & 0.4 & Sedang \\
\hline 19 & 2.3 & 3.1 & 0.5 & Sedang \\
\hline 20 & 2.1 & 2.9 & 0.4 & Sedang \\
\hline 21 & 2.3 & 2.9 & 0.4 & Sedang \\
\hline 22 & 2.4 & 3.1 & 0.4 & Sedang \\
\hline 23 & 2.3 & 3 & 0.4 & Sedang \\
\hline 24 & 2.4 & 3.1 & 0.4 & Sedang \\
\hline 25 & 2.1 & 2.7 & 0.3 & Sedang \\
\hline & & Rata-rata & $\mathbf{0 . 4}$ & Sedang \\
\hline & & & &
\end{tabular}

Tabel di atas menjelaskan hasil pengamatan kreativitas anak sebelum dan sesudah pembelajaran menggunakan eksperimen kapilaritas pada pertumbuhan tanaman. Berdasarkan tabel di atas hasil pretest dan posttest dilakukan uji gain ternormalisasi untuk mengetahui adanya peningkatan kreativitas anak sebelum dan sesudah pembelajaran. Hasilnya, terjadi peningkatan kreativitas anak pada pembelajaran kapilaritas terhadap pertumbuhan tanaman dengan $n$-gain sebesar 0.4 kriteria sedang. Hal ini terjadi karena untuk melatih kreativitas anak tentunya harus dilakukan secara terus-menerus, sedangkan pembelajaran ini hanya dilakukan selama $4 \mathrm{x}$ pertemuan sehingga peningkatan kreativitas anak masih dalam kategori sedang. Hasil ini sesuai dengan pendapat Dere (2019) bahwa membuat kegiatan yang berkaitan dengan lingkungan yang dibuat di kelas dan mendukung kreativitas memengaruhi kreativitas anak-anak secara positif. Sejalan dengan itu, Mulyasa (2017:194) juga berpendapat bahwa pembelajaran PAUD berbasis kreativitas dapat dilakukan antara lain melalui karya nyata, imajinasi, eksplorasi, eksperimen, proyek, bahasa, dan musik. 


\section{PENUTUP}

\section{Simpulan}

Pembelajaran kapilaritas terhadap pertumbuhan tanaman memberikan peningkatan terhadap kreativitas anak. Hasil tersebut dapat dilihat berdasarkan peningkatan skor kreativitas anak antara sebelum dan sesudah menerapkan pembelajaran kapilaritas pada pertumbuhan tanaman. Sehingga hipotesis penelitian bahwa pembelajaran kapilaritas terhadap pertumbuhan tanaman dapat melatih kreativitas anak kelompok B di TK PKK Tunas Bangsa, Soko, Tuban telah terbukti.

Melatih anak untuk kreatif harus dilakukan secara terus-menerus dan berkesinambungan. Pembelajaran harus dilakukan secara aktif dan interaktif untuk menstimulasi kreativitas anak. Dalam hal ini guru hanya bertindak sebagai fasilitator, sedangkan yang berperan aktif dalam pembelajaran adalah anak. Pembelajaran ini selain mengembangkan kreatifitas anak juga akan mengembangkan kemampuan anak untuk berpikir kritis karena pembelajaran dilakukan dengan eksperimen yang membuat anak penasaran dan antusias dalam pembelajaran.

\section{DAFTAR PUSTAKA}

Asmawati, Luluk. (2017). Peningkatan Kreativitas Anak Usia Dini Melalui Pembelajaran Terpadu Berbasis Kecerdasan Jamak. Jurnal Pendidikan Anak Usia Dini 11(1), 145-164. DOI: https://doi.org/10.21009/JPUD.111.10

Aydin, Elif. (2019). The Effect of Cultural Intelligence and Creative Thinking on the

Practical Technical Capabilities of Trabzon University Physical Education

Students. Asian Journal of Education and Training 5(2). DOI: 10.20448/journal.522.2019.52.392.396.

Dere, Zeynep. (2019). Investigating the Creativity of Children in Early Childhood Education Institutions. Universal Journal of Educational Research 7(3): 652658. DOI: 10.13189/ujer.2019.07030. 
Dwirahmah, Erina. (2013). Peningkatan Kreativitas Melalui Pendekatan Inquiry dalam Pembelajaran Sains. Jurnal Pendidikan Anak Usia Dini 7(2).

Ibrahim, Muslimin. (2010). Dasar-Dasar Proses Belajar Mengajar. Surabaya: Unesa University Press.

Mulyasa. (2017). Strategi Pembelajaran PAUD. Bandung: PT Remaja Rosdakarya.

Mursid. (2017). Pengembangan Pembelajaran PAUD. Bandung: PT Remaja Rosdakarya.

Morrison, George S. (2012). Dasar-Dasar Pendidikan Anak Usia Dini (PAUD): Edisi kelima. Jakarta: PT Indeks.

Padilah. (2018). Peningkatan Kreativitas Melalui Metode Pembelajaran Inkuiri (Penelitian Tindakan Anak Usia 5-6 Tahun di PAUD SPS ARRAYAN TAHUN 2017). Jurnal Caksana - Pendidikan Anak Usia Dini 1(1).

Pusat Penilaian Pendidikan Balitbang Kemendikbud. (2019). Pendidikan di Indonesia Belajar dari Hasil PISA 2018. Badan Penelitian dan Pendidikan Kementrian Pendidikan dan Kebudayaan.

Rosandi, A, E Sudibyo, SN Hidayati. (2014). Penerapan Model Pembelajaran Kooperatif Tipe Tgt Untuk Meningkatkan Hasil Belajar Akademik dan Keterampilan Sosial Siswa Smpn 2 Singgahan Tuban. Jurnal Pendidikan Sains 2(2). Jurnal Prisma Sains: Jurnal Pengkajian Ilmu dan Pembelajaran Matematika dan IPA IKIP Mataram 4(1).

Rosandi, A, T Tjandrakirana, I Supardi. (2016). Pengembangan Multimedia IPA Berbasis Flash untuk Meningkatkan Literasi Sains Siswa SMP.

Siburian1, Jodion, Aloysius Duran Corebima, Ibrohim, Murni Saptasari. (2019). The Correlation Between Critical and Creative Thinking Skills on Cognitive Learning Results. Eurasian Journal of Educational Research 81 99-114.

Uce, Loeziana. (2017). The Golden Age: Masa Efektif Merancang Kualitas Anak. Bunayya: Jurnal Pendidikan Anak 1 (2), 77-92.

Wojciehowski, Mandi \& Julie Ernst. (2018). Creative by Nature: Investigating the Impact of Nature Preschools on Young Children's Creative Thinking. The International Journal of Early Childhood Environmental Education, 6(1), p. 3 